\title{
INCREASED CELL EFFICIENCY IN InGaAs THIN FILM SOLAR CELLS WITH DIELECTRIC AND METAL BACK REFLECTORS
}

\author{
Koray Aydin, Marina S. Leite and Harry A. Atwater \\ Thomas J. Watson Laboratories of Applied Physics, California Institute of Technology, Pasadena, CA 91125.
}

\begin{abstract}
Compound single junction and multijunction solar cells enable very high photovoltaic efficiencies by virtue of employing different band gap materials in seriesconnected tandem cells to access the full solar spectrum. Researchers focused on improving the electrical properties of solar cells by optimizing the material growth conditions, however relatively little work to date has been devoted to light trapping and enhanced absorption in III-V compound solar cells using back reflectors. We studied absorption enhancement in InGaAs and InGaAsP thin film solar cells by means of numerical modeling. Flat dielectric and metal back reflectors that might be introduced into the solar cell via wafer-bonding, epitaxial lift-off or deposition techniques have been shown to increase the short circuit current and the photovoltaic efficiency of solar cells.
\end{abstract}

\section{INTRODUCTION}

Multi-junction solar cells based on III-V compound semiconductors are the most efficient photovoltaic devices with record-level efficiencies over $40 \%[1,2]$. Semiconductors with different band gap energies are connected in series to absorb wider range of the solar spectrum efficiently. Not only band gap energies but also lattice constants of III-V compounds could be tuned by the composition of ternary and quaternary semiconductors providing a wide range of possibilities for material growth on various substrates such as $\mathrm{Si}, \mathrm{Ge}, \mathrm{InP}$ and $\mathrm{GaAs}$. Lattice-matching growth condition limits the materials of certain band gap energies to be grown for multi-junction solar cells. Therefore, one needs to utilize more than three junctions to reach ultra-high efficiencies requiring alternative techniques to bring lattice mismatched materials together such as metamorphic growth, wafer bonding, and mechanical stacking [3]. Metamorphic growth of In$\mathrm{GaP} / \mathrm{InGaAs} / \mathrm{Ge}$ and InGaP/InGaAs/InGaAs solar cells enabled $40.7 \%$ [1] and $40.8 \%$ [2] efficiencies. The use of InP substrates have drawn our interest due to the possibility of access lattice matched III-V alloys, such as $\ln _{0.53} \mathrm{Ga}_{0.47} \mathrm{As}$, and defect-free strained layers with band gap energies varying from 0.8 to $2.0 \mathrm{eV}$. Recently, wafer bonding of $\mathrm{InP}$ wafers to $\mathrm{Si}$ handle substrates was proposed as a way to reduce fabrication costs and increase solar cell performance [4]. It was previously shown that an oxide layer formed during the wafer bonding of InP wafer to $\mathrm{Si}$ substrate, which results in a higher short circuit current [4]. Here, we studied the effect of different optical reflection layers, both dielectric and metal, on InGaAs thin film solar cell performance by device modeling and numerical simulations.

\section{DEVICE MODELLING OF InGaAs SOLAR CELLS}

We modeled a single junction InGaAs solar cell (Fig. 1a) on an InP substrate by using AFORS-HET, an opensource program for simulating thin-film heterojunction solar cells [5]. The optical generation rate is calculated by using a coherent multiple reflection model, rather than a Lambert-Beer absorption model. Since the coherence length of light is comparable to the thickness of active region of solar cell, multiple reflections occur at the interfaces of different materials for thin-film solar cells $[6,7]$.

\section{(a)}

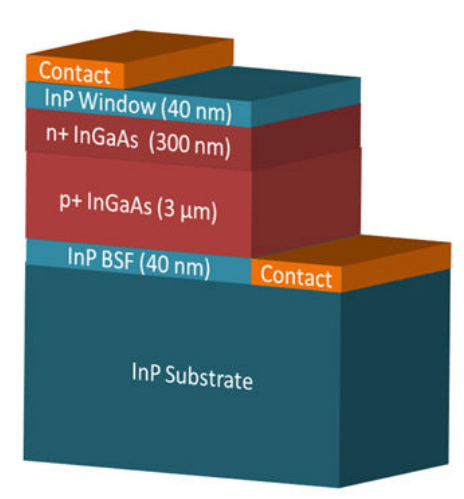

(b)

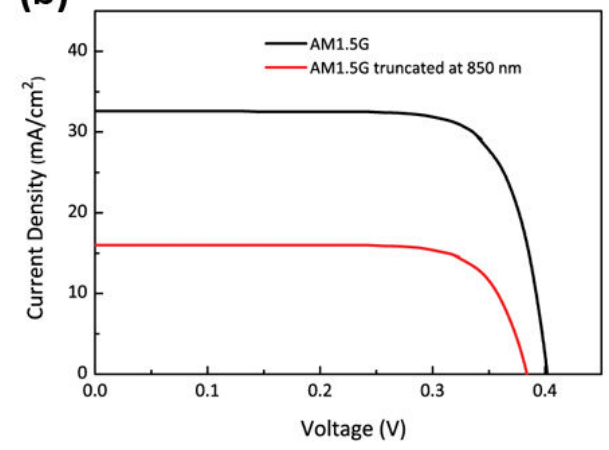

Fig. 1. (a) Schematic drawing of the modeled InGaAs solar cell (b) Simulated I-V curve for InGaAs solar cell under AM1.5G full and AM1.5G truncated at $850 \mathrm{~nm}$ illuminations. 
The modeled device is shown in Fig. 1a. Solar cell has $n$ type InGaAs emitter and $p$ type InGaAs base with bandgap energy of $0.74 \mathrm{eV}$, nominally lattice matched to $\operatorname{InP}$. The thicknesses of emitter and base are 0.3 and 3.0 $\mu \mathrm{m}$, respectively. InP is used both as a window and backsurface-field (BSF) layers. Light current-voltage (I-V) characteristics were calculated under illuminated with AM1.5 global illumination (Fig. 1(b)). Calculated short circuit current $\left(J_{\mathrm{sc}}\right)$ and open circuit voltage $\left(V_{\text {oc }}\right)$ are $32.6 \mathrm{~mA} / \mathrm{cm}^{2}$ and $0.4 \mathrm{~V}$, yielding an efficiency of $10.1 \%$. We calculated light $I-V$ response of InGaAs subcell under AM1.5G truncated at $850 \mathrm{~nm}$, to mimic the optical configuration of bottom cell below a GaAs upper cell (Fig. 1(b)), for which $J_{\text {sc }}$ $=16.1 \mathrm{~mA} / \mathrm{cm}^{2}$ and $V_{\text {oc }}=0.38 \mathrm{~V}$ with $4.7 \%$ efficiency.
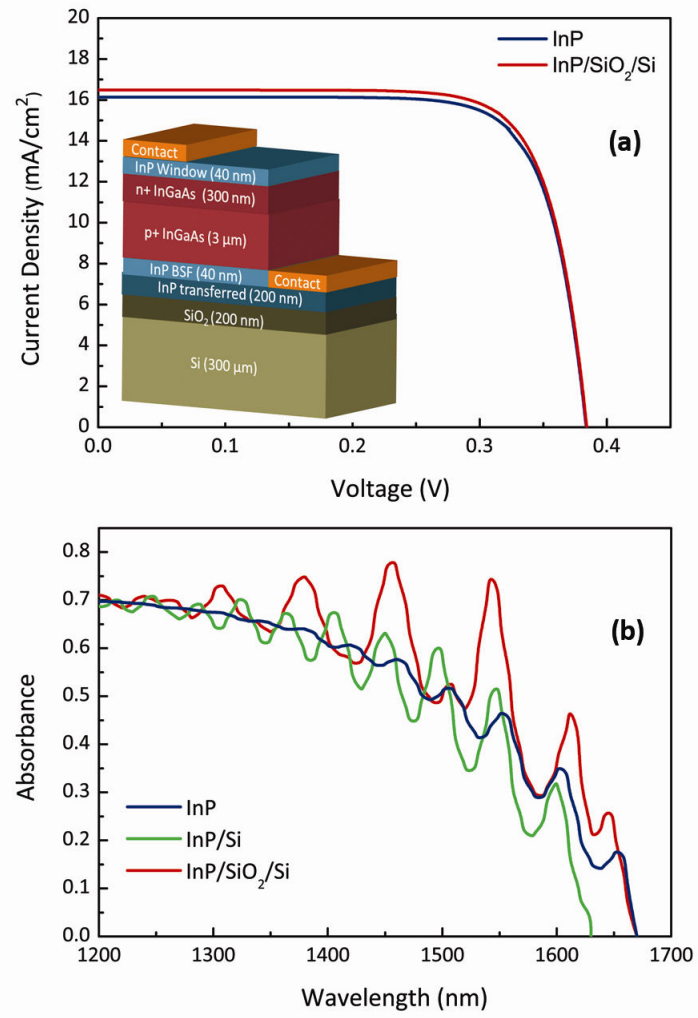

Fig. 2. (a) Simulated $I-V$ response for $I n G a A s$ solar cells with $\operatorname{InP}$ and $\operatorname{InP} / \mathrm{SiO}_{2} / \mathrm{Si}$ substrates. (Inset) schematic drawing of InGaAs subcell on $\operatorname{InP} / \mathrm{SiO}_{2} / \mathrm{Si}$ laminate substrate (b) Absorbance spectra of solar cells on different types of substrates.

\section{DIELECTRIC BACK REFLECTORS}

The InGaAs subcell is then modeled on a $200 \mathrm{~nm} \mathrm{InP}$ (bonded layer), with $200 \mathrm{~nm} \mathrm{SiO}$ (oxide formed during wafer bonding) and $300 \mu \mathrm{m}$ Si (handle substrate) (inset Fig. 2a) [4]. In AFORS-HET, one could define optical layers by inserting complex refractive index data ( $n$ and $k$ ) above or below the electrical layers, i.e. the layers between the contacts. Same InGaAs subcell is modeled with additional optical layers of $\mathrm{SiO}_{2}$ and $\mathrm{Si}$. We observed an increase in $J_{\mathrm{sc}}$ for this layer structure to $16.65 \mathrm{~mA} / \mathrm{cm}^{2}$, while $V_{\text {oc }}$ remains unchanged (Fig. 2a). Since the active layers in both devices are same, the increased short circuit can be explained by light trapping effects due to the reflection from the layers with different refractive indices. $\mathrm{SiO}_{2}$ has lower refractive index compared to $\mathrm{Si}$ and $\operatorname{lnP}$. The low refractive index layer sandwiched between high index layers causes higher reflection from the interfaces. Some portion of light that is not absorbed within the semiconductor layer, is reflected back into the solar cell and the amount of light absorbed at the base layer increases.

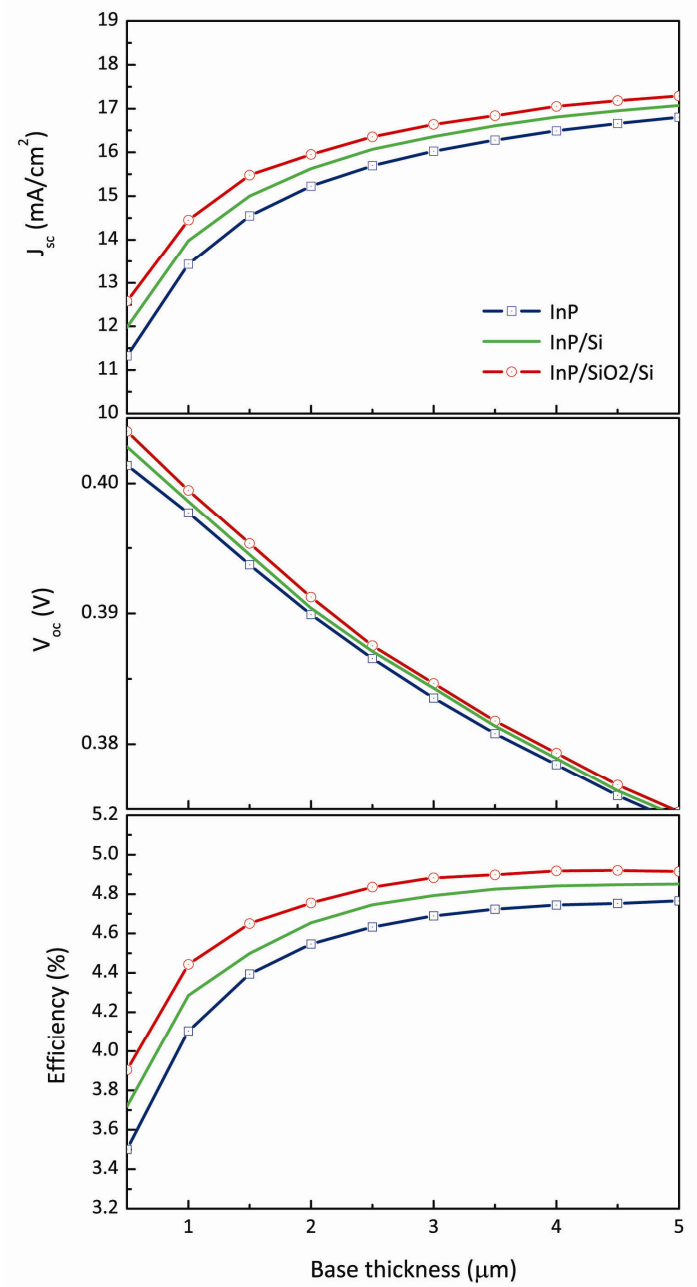

Fig. 3. Calculated short circuit currents (top), open circuit voltages (middle) and cell efficiencies (bottom) as a function of base thickness of InGaAs subcell on $\operatorname{lnP}, \operatorname{InP} / \mathrm{Si}$ and $\mathrm{InP} / \mathrm{SiO}_{2} / \mathrm{Si}$ substrates.

Amount of light that is absorbed within the InGaAs base layer is calculated using AFORS-HET. The absorbance of InGaAs solar on three different substrates, namely $\operatorname{InP}, \operatorname{InP} / \mathrm{Si}$ and $\operatorname{InP} / \mathrm{SiO}_{2} / \mathrm{Si}$ substrates show different spectral behaviors. (Fig. 2b). At higher wavelengths close 
to InGaAs band edge, one can observe the oscillations in the absorbance due to the reflections from the InP/air interface. For InP/Si substrate, refractive index difference causes additional reflections from InP/Si interface. Absorbance of InGaAs solar cells was increased further with the $\mathrm{InP} / \mathrm{SiO}_{2} / \mathrm{Si}$ substrate, due to the reflections of light from the low-index $\mathrm{SiO}_{2}$ layer.

Additional simulations were performed to study the effect of the base thickness of InGaAs solar cell on $J_{\text {sc }}, V_{\text {oc }}$ and cell efficiency with different substrate types (Fig. 3). An efficiency of $4.7 \%$ was obtained with a $3 \mu \mathrm{m}$ thick In$\mathrm{GaAs}$ base on InP substrate; whereas a similar efficiency could be achieved with a $1.5 \mu \mathrm{m}$ thick InGaAs base layer on $\mathrm{InP} / \mathrm{SiO}_{2} / \mathrm{Si}$ substrate. The amount of increase in the short circuit current and the solar cell efficiency is higher for thinner base thicknesses. Incorporating dielectric layers such as $\mathrm{SiO}_{2}$ within solar cells during wafer bonding could be a promising method to further reduce the cost of multijunction solar cells and yield higher photovoltaic efficiencies.

Dielectric contrast between the optical layers could be further increased by stacking layers with different refractive indices, such as $\mathrm{SiO}_{2}-\mathrm{Si}_{3} \mathrm{~N}_{4}-\mathrm{SiO}_{2}$. Table 1 summarizes and compares the short circuit currents and efficiencies of InGaAs single junction solar cells for different substrate types. The InP/SiO $/ \mathrm{Si}_{3} \mathrm{~N}_{4} / \mathrm{SiO}_{2} / \mathrm{Si}$ substrate with $200 \mathrm{~nm}$ oxide and nitride alternating layers provides higher $J_{s c}$ and efficiency for the InGaAs solar cell, essentially due to the increased absorption caused by additional reflections from the nitride layer. On the other hand, short circuit current of InGaAs cell on $\ln P / S_{i}{ }_{2} / S_{3} N_{4} / S i$ is smaller than $\operatorname{InP} / \mathrm{SiO}_{2} / \mathrm{Si}$ substrate. Since the refractive index contrast between silicon nitride and silicon are smaller than the silicon oxide-silicon, the reflection from $\mathrm{Si}$ interface is reduced.

\begin{tabular}{|c|c|c|}
\hline Substrate & $\begin{array}{c}J_{\text {sc }} \\
\left(\mathbf{m A} / \mathbf{c m}^{-2}\right)\end{array}$ & Efficiency \\
\hline $\operatorname{InP}$ & 16.16 & $4.73 \%$ \\
\hline $\operatorname{InP} / \mathrm{Si}$ & 16.38 & $4.80 \%$ \\
\hline $\operatorname{InP} / \mathrm{SiO}_{2} / \mathrm{Si}$ & 16.65 & $4.89 \%$ \\
\hline $\operatorname{InP} / \mathrm{SiO}_{2} / \mathrm{Si}_{3} \mathrm{~N}_{4} / \mathrm{Si}$ & 16.48 & $4.83 \%$ \\
\hline $\operatorname{InP} / \mathrm{SiO}_{2} / \mathrm{Si}_{3} \mathrm{~N}_{4} / \mathrm{SiO}_{2} / \mathrm{Si}$ & 16.75 & $4.92 \%$ \\
\hline
\end{tabular}

Table 1. Short circuit currents and efficiencies of InGaAs subcells on different substrate types with dielectric stacks.

\section{METAL BACK REFLECTORS}

Although dielectric layers with low refractive indices provide sufficient refractive index contrast with $\mathrm{InP}$ and $\mathrm{Si}$ to reflect some portion of the incoming light, metals are very good mirrors especially at infra-red wavelengths. We took a further step and replaced $\mathrm{SiO}_{2}$ layer with $\mathrm{Ag}$ mirror to form an InP/Ag/Si substrate. (inset of Fig. 4a) Since this substrate is not practical in terms of wafer bonding and III$\mathrm{V}$ growth process, we also modeled InGaAs cell on an
InP/Si/Ag substrate which could easily be fabricated by depositing $\mathrm{Ag}$ after solar cell growth. Complex refractive index data for $\mathrm{Ag}$ is used to define the optical layer. Calculated light $I-V$ curves indicated further increase in $J_{\mathrm{sc}}$ (16.99 $\mathrm{mA} / \mathrm{cm}^{2}$ ) and solar cell efficiency (5.0\%) for InP/Si/Ag substrates (Fig. 4a). Bringing together the dielectric and metal reflector layers in a single design with a virtual $\operatorname{lnP} / \mathrm{SiO}_{2} / \mathrm{Si} / \mathrm{Ag}$ substrate provided the highest efficiency with $5.07 \%$. Figure $4 \mathrm{~b}$ plots the absorbances of InGaAs subcell for InP/Si, InP/Ag/Si, and InP/Si/Ag substrates. Presence of Ag mirror enhances the light absorption in the active layer of InGaAs solar cell as evident from the oscillations in absorbance spectra of various substrates with Ag mirrors.
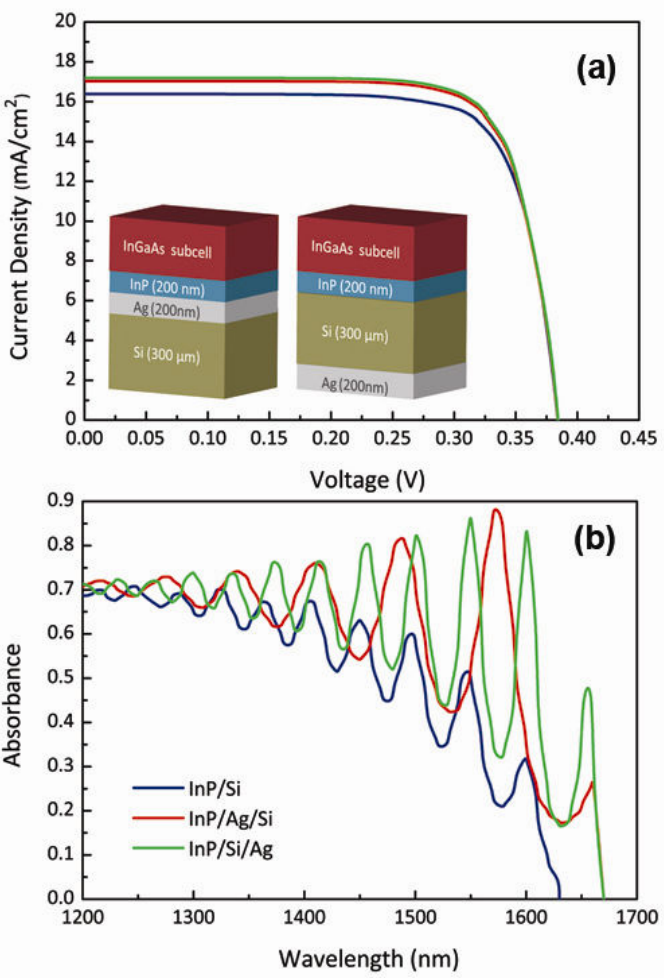

Fig. 4. Calculated (a) $I-V$ curves and (b) absorbances of InGaAs solar cells with the presence of $\mathrm{Ag}$ layer in the substrate. (inset) two different configurations with Ag above and below Si substrate.

\begin{tabular}{|c|c|c|}
\hline Substrate & $\begin{array}{c}\boldsymbol{J}_{\text {sc }} \\
\left(\mathbf{m A} / \mathbf{c m}^{-2}\right)\end{array}$ & Efficiency \\
\hline InP/Ag/Si & 17.01 & $5.00 \%$ \\
\hline $\operatorname{InP} / \mathrm{Si} / \mathrm{Ag}$ & 16.99 & $5.00 \%$ \\
\hline $\operatorname{InP} / \mathrm{SiO}_{2} / \mathrm{Si} / \mathrm{Ag}$ & 17.31 & $5.07 \%$ \\
\hline
\end{tabular}

Table 2. Short circuit currents and efficiencies of InGaAs subcells on different substrates with Ag back side mirrors. 
We also modeled InGaAs solar cells with the presence of dielectric and metal reflectors, on a $\mathrm{InP} / \mathrm{SiO}_{2} / \mathrm{Si} / \mathrm{Ag}$ substrate. Table 2 provides the short circuit currents and efficiencies of solar cells with metal and dielectric-metal back mirrors. The efficiency of InGaAs solar cell is increased from $5.00 \%$ to $5.07 \%$ with the additional oxide layer to $\ln \mathrm{P} / \mathrm{Si} / \mathrm{Ag}$ substrate.

(a)

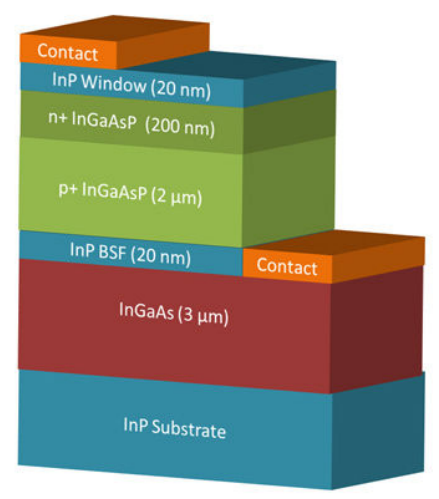

(b)

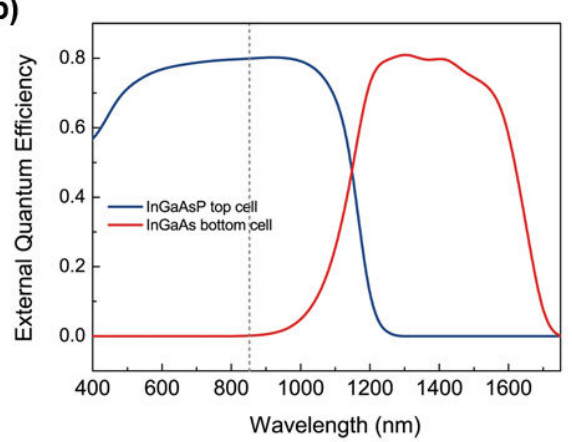

(c)

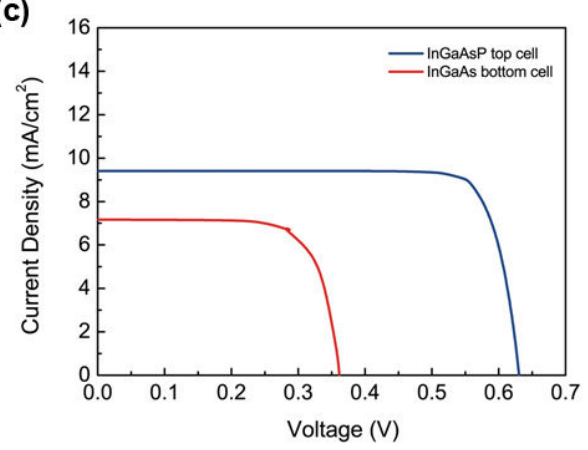

Fig. 5. (a) InGaAsP solar cell (b) External quantum efficiencies and (c) light $I-V$ characteristics of top InGaAsP and bottom InGaAs solar cells.

\section{InGaAsP THIN-FILM SOLAR CELLS}

The current record efficiency was achieved using an InGaP/InGaAs/InGaAs triple-junction solar cell via metamorphic growth [2]. Efficiencies of III-V multijunction thin film solar cells could be increased by utilizing four or more junctions and thus splitting the solar spectrum between absorbing layers with different bandgap energies. For this purpose, materials with band gap energies around $1 \mathrm{eV}$ are required to efficiently split the solar spectrum. InGaAsP is a promising quartenary III-V semiconductor material that can be grown lattice matched to $\operatorname{lnP}$. Ge bottom cell of InGaP/GaAs/Ge three-junction solar cells could be replaced with a tandem InGaAsP/InGaAs cell to increase the photovoltaic efficiency $[8,9]$. We modeled an InGaAsP topcell for such a two junction tandem cell. Modeled device is schematically drawn in Fig. $5 a$, where InGaAsP is utilized as the emitter and the base with the bandgap energy of $1.03 \mathrm{eV}$. Thicknesses of the emitter and the base layers are $200 \mathrm{~nm}$ and $2 \mu \mathrm{m}$. Electrical losses due to the tunnel junction are not taken into account, and we treated $3 \mu \mathrm{m}$ thick InGaAs as an optical layer to simulate the reflection due to InGaAs layer.

We illuminated solar cell with AM1.5G with full spectrum to calculate the external quantum efficiency of InGaAsP topcell which is plotted in Fig. $5 b$ with blue line. The band offset at $1200 \mathrm{~nm}$ corresponds to the band edge of InGaAsP. We also calculated the EQE of InGaAs bottom cell. In this case, we utilized $2.2 \mu \mathrm{m}$ thick optical InGaAsP layer on top of InGaAs cell, to mimic the behavior of an InGaAs bottom cell under an InGaAsP top cell. Light I-V curves of top and bottom cells are given in Fig. 5c. Simulations show that the current limiting cell is the InGaAs bottom cell. Since a current-matched junction is required for an efficient operation of the solar cell, we varied the base thicknesses of both InGaAsP and InGaAs solar cells to match the currents of bottom and top cell thicknesses. Figure 6 plots the light I-V characteristics of top InGaAsP and bottom InGaAs cells, as well as the tandem InGaAsP/InGaAs solar cell, all on InP substrates.

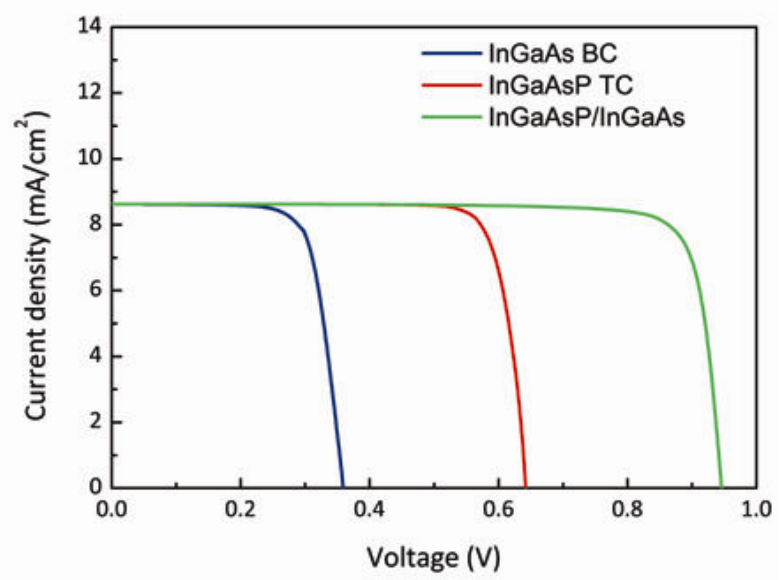

Fig. 6. Light $\mathrm{I}-\mathrm{V}$ characteristics of current-matched InGaAsP/InGaAs tandem cell and their constituting subcells. 


\begin{tabular}{|c|c|c|c|}
\hline Cell & $\begin{array}{c}J_{\text {sc }} \\
\left(\mathbf{m A} / \mathbf{c m}^{-2}\right)\end{array}$ & $\begin{array}{c}\mathbf{V}_{\text {oc }} \\
(\mathbf{m V})\end{array}$ & $\begin{array}{c}\text { Eff } \\
(\%)\end{array}$ \\
\hline InGaAsP TC & 8.62 & 643 & 4.6 \\
\hline InGaAs BC & 8.62 & 359 & 2.3 \\
\hline InGaAsP/InGaAs MJ & 8.62 & 944 & 6.8 \\
\hline Cell & $\begin{array}{c}\mathbf{J}_{\mathbf{s c}} \\
\left(\mathbf{m A} / \mathbf{c m}^{-2}\right)\end{array}$ & $\begin{array}{c}\mathbf{V}_{\text {oc }} \\
(\mathbf{m V})\end{array}$ & $\begin{array}{c}\text { Eff } \\
(\%)\end{array}$ \\
\hline InGaAsP TC & 9.00 & 641 & 4.8 \\
\hline InGaAs BC & 9.00 & 360 & 2.7 \\
\hline InGaAsP/InGaAs MJ & 9.00 & 943 & 7.2 \\
\hline
\end{tabular}

Table 3. Short circuit current, open voltage and efficiencies of InGaAsP top cell, InGaAs bottom cell and InGaAsP/InGaAs tandem cells on InP (top, blue table) and InP/SiO$/ 2$ i substrate (bottom, red table).

Table 3 summarizes the photovoltaic cell parameters for InGaAsP top cell, InGaAs bottom cell and InGaAsP/InGaAs current-matched tandem cells on InP substrate (top, blue table) and $\mathrm{InP} / \mathrm{SiO}_{2} / \mathrm{Si}$ laminate substrate (bottom, red table). Short circuit current of the current limiting InGaAs bottom cell increases with the utilization of InP/SiO2/Si substrate instead of bare InP substrate. Cell thicknesses are then optimized to match the currents of bottom and top cells with the $\mathrm{InP} / \mathrm{SiO}_{2} / \mathrm{Si}$ substrate. Overall efficiency of InGaAsP/InGaAs cell increases by a factor of $0.4 \%$ from $6.8 \%$ to $7.2 \%$. One can also include metal back side mirrors to further increase the short circuit currents and efficiencies of InGaAsP/InGaAs tandem cells.

\section{CONCLUSIONS}

We presented the results of our modeling efforts for a single junction InGaAs solar cell including $I-V$ curves, spectral responses and absorbances for different substrates with dielectric and/or metallic layers used as back reflectors. Reflection through thin optical layers increase the amount of light absorbed within the active region of solar cell which in turn increase the short circuit current and solar cell efficiency. Detailed analyses for optimized dielectric and/or metallic layers with different types and varying thickness were provided. InGaAsP/InGaAs tandem solar cells are modeled and the short circuit current of the current limiting InGaAs subcell was increased by dielectric back side mirrors. Utilization of dielectric and metal mirrors could enable even higher efficiencies in multi-junction III-V compound semiconductor solar cells.

\section{ACKNOWLEDGEMENTS}

This work was supported by the Department of Energy, and the Center for Science and Engineering of Materials, an NSF Materials Research Science and Engineering Center at Caltech.

\section{REFERENCES}

[1] R. R. King, "Multijunction solar cells: Record breakers," Nature Photonics 2, 284 (2008).

[2] J. F. Geisz et al., " $40.8 \%$ efficient inverted triplejunction solar cell with two independently metamorphic junctions," Applied Physics Letters 93, 123505 (2008).

[3] M. J. Griggs, D. C. Law, R. R. King, A. C. Ackerman, J. M. Zahler, and H. A. Atwater, "Design Approaches and materials processes for ultrahigh efficiency lattice mismatched multi-junction solar cells," Proc. of IEEE $4^{\text {th }}$ World Conference on Photovoltaic Energy Conversion, 857-860 (2006)

[4] J. M. Zahler, K. Tanabe, C. Ladous, T. Pinnington, F. D. Newman, and H. A. Atwater, "High efficiency InGaAs solar cells on Si by InP layer transfer," Journal of Applied Physics 91, 012108 (2007).

[5] R. Stangl, A. Froitzheim, M. Kriegel, T. Brammer, S. Kirste, L. Elstner, H. Stiebig, M. Schmidt, and W. Fuhs, "AFORS-HET, a numerical PC-program for simulation of heterojunction solar cells, Version 1.1 (open-source on demand), to be distributed for public use," Proc. PVSEC-19, 19th European Photovoltaic Solar Energy Conference, Paris, France, June 2004.

[6] G. Letay, M.Breselge, and A. W. Bett, "Calculating the generation function of III-V solar cells," Proc. of IEEE $3^{\text {rd }}$ World Conference on Photovoltaic Energy Conversion, 741-744 (2003)

[7] M. Hermle, G. Letay, S. P. Phillipps, and A. W. Bett, "Numerical simulation of tunnel diodes for multi-junction solar cells," Prog. Photovolt: Res. Appl. 16, 409 (2008).

[8] N. Szabo, B. E. Sagol, U. Seidel, K. Schwarzburg, and T. Hannapel, "InGaAsP/InGaAs tandem cells for a solar cell configuration with more than three junctions," Phys. Stat. Sol. (RRL) 2, 254 (2008).

[9] B. E. Sagol, U. Seidel, N. Szabo, K. Schwarzburg, and T. Hannapel, "Basic concepts and interfacial aspects of high-efficiency III-V multijunction solar cells," Chimia 61, 775 (2007). 